\title{
Importance of functional nutrition components on new Coronavirus disease (COVID-19) and other viral communicable diseases
}

\author{
Serhan MOHAMMED, Nilgün ÖZDEMİR, Ahmet Hilmi ÇON
}

Cite this article as:

Mohammed, S., Özdemir, N. Çon, A.H. (2021). Importance of functional nutrition components on new Coronavirus disease (COVID-19) and other viral communicable diseases. Food and Health, 7(4), 286-299. https://doi.org/10.3153/FH21030

Ondokuz Mayis University,

Engineering of Faculty,

Food Engineering Department, Samsun, Turkey

ORCID IDs of the authors: S.M. 0000-0003-2450-7191

N.Ö. 0000-0002-4517-9214

A.H.Ç. 0000-0002-1225-0133

Submitted: 30.12 .2020

Revision requested: 09.02 .2021

Last revision received: 21.02 .2021

Accepted: 22.02 .2021

Published online:12.09.2021

Correspondence: Nilgün ÖZDEMIR

E-mail: nilgun.ozdemir@omu.edu.tr

\section{ABSTRACT}

There are no foods to prevent or treat the coronavirus alone; however, it has been proven that a healthy and balanced nutrition is crucial for health, particularly in times when the immune system might need to fight back. The present study provides insights about the properties of bioactive components of foods and herbs as a possible adjuvant support the human immune system against infections. Also, has focused on the interactions of the intestinal microbiota with human health in the treatment of Covid-19 and other viral infections. More research with strong recommendations is needed to better understand causality.

Keywords: Functional nutrition, Covid-19, Viral infection, Bioactive compound

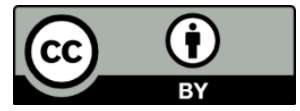

(c) 2021 The Author(s)

Available online at http://jfhs.scientificwebjournals.com 


\section{Introduction}

Viruses are microscopic obligate organisms, which contain either an RNA or DNA genome surrounded by a protective which virus-coded protein coat. Viruses need host cells with metabolic and biosynthetic mechanisms of eukaryotic or prokaryotic cells for their propagation and survival (HerreroUribe, 2011).

Most viruses are harmful to their hosts and can cause fatal diseases for humans. The number of potential pathogens worldwide is enormous; however, disease research and development resources are limited. For this reason, the World Health Organization (WHO) annually announces lists of priority diseases that are at risk of turning into a major epidemic. In Table 1, these lists published by the WHO in recent years include the main diseases and their causative agent that cause viruses and pose a potential threat(Bloom \& Cadarette, 2019). The last one, Covid-19, which emerged in the city of Wuhan in China in 2019, and whose effect has still continued all over the world. As of March 11, 2020, the Covid-19 was declared a pandemic by the WHO.

When such viral outbreaks occur, such as the current dramatic emergency, for control of pandemic, it is first necessary to avoid these viral outbreaks. It is stated that keeping the immune system strong is as important as adhering to social isolation and hygiene rules to be protected (Pellegrini et al., 2020). One of the duties of individuals to keep the immune system strong is a healthy and balanced diet. There is no food or food supplement that provides protection from these epidemic diseases or supports the treatment of the disease. Also, a single food is not enough to keep the immune system strong. However, it is very important to eat a healthy and balanced diet, to know the content of foods and to become conscious about it (Table 1).

\section{The Role of Nutrition in Viral Disease}

Good nutrition has a positive impact on immune function. In various studies that have been conducted on the relationship between viral diseases and nutrition (Pellegrini et al., 2020), mainly emphasized to strengthen the immune system. In particular, it has been stated that deficiencies or suboptimal status of certain micronutrients adversely affect the immune function and resistance to infections decreases. The micronutrients comprise of minerals such as zinc $(\mathrm{Zn})$, iron $(\mathrm{Fe})$, selenium $(\mathrm{Se})$, magnesium $(\mathrm{Mg})$ and copper $(\mathrm{Cu})$, vitamins such as vitamin A, B6, B12, C, D, E, K and folate, and also; some bioactive compounds such as natural antioxidant polyphenols, sterols, bioactive peptides, organic acids, and essential fatty acids. The bioactive compounds have been derived from macronutrient through the use of methodologies such as enzymatic hydrolysis and/or fermentation process (Gombart,
Pierre, \& Maggini, 2020). Another phenomenon that strengthens the immune system is probiotic microorganisms and their metabolites. Probiotic microorganisms produce various metabolites with antioxidant, antimicrobial, anticancer, and anti-inflammatory properties. There are several studies on the antiviral properties of probiotic cells or their metabolites (Lehtoranta et al., 2014). In this study, it was investigated the important of some micronutrients and/or probiotic microorganisms in treatment or preventing of viral diseases.

\section{Zinc (Zn)}

The biological function of zinc, an essential trace element; the catalytic activity of enzymes is divided into three categories as the structural integrity of proteins and the regulation of gene expression. It contains approximately 250 protein $\mathrm{Zn}$ including various enzymes such as angiotensin converting enzyme, deoxyribonucleic acid (DNA) polymerase, ribonucleic acid (RNA) polymerase, and alkaline phosphatase. Several of evidence has accrued in past years to make evident the antiviral activity of zinc against adversity of viruses, and via numerous mechanisms (Li et al., 2019). Some studies have demonstrated greater response or tolerance to interferon therapy (administration of interferon, a substance in the structure of the protein that acts against bacteria, parasites, viruses, and gums, to patients infected with viruses) by administering zinc to patients infected with hepatitis $\mathrm{C}$ virus (HCV). Zinc is a powerful antioxidant and plays a central role in the immune system, adequate amounts of zinc are essential to maintain the integrity of the immune system (Li et al., 2019). It has known that Zinc-finger antiviral proteins (ZAP) which one of both human and animal cells, can inhibit the replication of viruses by stopping the accumulation of viral RNA in the cytoplasm, which can lead to innate immune mechanisms against infections (Read, Obeid, Ahlenstiel, \& Ahlenstiel, 2019). In addition, zap proteins have different mechanisms; inhibition of viral protease, viral transcription, and viral polyprotein tertiary structure etc., but they are not fully understood. In a study related to virus and $\mathrm{Zn}$ (Chiu et al., 2018), it was investigated the antiviral potential of human ZAP against three viruses; Japanese encephalitis virus (JEV), dengue virus (DENV) and Zika virus (ZIKV). As the result, no significant antiviral effect of ZAP was observed against DENV and ZIKV, it was identified JEV as the ZAP-sensitive flavivirus. In another study, it was demonstrated that increased intracellular $\mathrm{Zn}^{2+}$ inhibits the replication of SARS-coronavirus (SARS-CoV) in cell culture. In a different study, it was demonstrated that zinc supplement $(30 \mathrm{mg} /$ day) increased the proliferation of T cells that take part in the cellular defense of the immune system, in elderly care home. These information shows that $\mathrm{Zn}$ is very important in nutrition. 
Table 1. Potential threatening epidemic viral diseases (Bloom \& Cadarette, 2019; CDC, 2020; Kuhn et al., 2010; WHO, 2020)

\begin{tabular}{|c|c|c|}
\hline Virus & Viral Diseases & Description \\
\hline MERS-CoV & $\begin{array}{l}\text { Middle East respiratory syndrome } \\
\text { coronavirus (MERS-CoV) }\end{array}$ & $\begin{array}{l}\text { A viral respiratory disease caused by a novel coronavirus that was } \\
\text { first identified in Saudi Arabia in } 2012 \text {. }\end{array}$ \\
\hline SARS-CoV & $\begin{array}{l}\text { Severe Acute Respiratory } \\
\text { Syndrome (SARS) }\end{array}$ & $\begin{array}{l}\text { A viral respiratory disease caused by a SARS-associated } \\
\text { coronavirus. }\end{array}$ \\
\hline Ebola virus & Ebola virus disease (EVD) & $\begin{array}{l}\text { One of six known species within the genus Ebola virus. Including } \\
\text { EBOV, cause a severe and often fatal hemorrhagic fever in humans } \\
\text { and other mammals, known as Ebola virus disease (EVD). }\end{array}$ \\
\hline Nipah virus & Nipah diseases & $\begin{array}{l}\text { A bat-borne virus that is associated with a highly fatal infection. } \\
\text { Nipah virus can also be transmitted through contaminated food or } \\
\text { directly between people. In infected people, it causes a range of ill- } \\
\text { nesses from asymptomatic (subclinical) infection to acute respira- } \\
\text { tory illness and fatal encephalitis. }\end{array}$ \\
\hline Phlebovirus & Rift valley fever (RVF) & $\begin{array}{l}\text { A viral disease most commonly seen in domesticated animals in } \\
\text { sub-Saharan Africa, People can get RVF through contact with } \\
\text { blood, body fluids, or tissues of infected animals, or through bites } \\
\text { from infected mosquitoes. }\end{array}$ \\
\hline $\begin{array}{l}\text { Zika virus } \\
\text { (ZIKV) }\end{array}$ & Zika & $\begin{array}{l}\text { A mosquito-borne flavivirus that was first identified in Uganda in } \\
1947 \text { in monkeys. }\end{array}$ \\
\hline Lassa virus & Lassa fever & $\begin{array}{l}\text { An acute viral haemorrhagic illness caused by Lassa virus, a } \\
\text { member of the arenavirus family of viruses. }\end{array}$ \\
\hline $\begin{array}{l}\text { Dengue virus } \\
\text { (DENV) }\end{array}$ & Dengue fever & $\begin{array}{l}\text { A mosquito-borne tropical disease caused by the dengue virus; } \\
\text { symptoms typically begin three to fourteen days after infection. }\end{array}$ \\
\hline $\begin{array}{l}\text { Human } \\
\text { immunodefici- } \\
\text { ency } \\
\text { virus (HIV) }\end{array}$ & $\begin{array}{l}\text { Acquired immunodeficiency } \\
\text { syndrome (AIDS) }\end{array}$ & $\begin{array}{l}\text { Two species of lentivirus (a subgroup of retrovirus) that infect hu- } \\
\text { mans, it causes acquired immunodeficiency syndrome (AIDS). }\end{array}$ \\
\hline Nairovirus & $\begin{array}{l}\text { Crimean-Congo } \\
\text { Hemorrhagic Fever (CCHF) }\end{array}$ & $\begin{array}{l}\text { Crimean-Congo hemorrhagic fever (CCHF) is caused by infection } \\
\text { with a tick-borne virus (Nairovirus) in the family Bunyaviridae. }\end{array}$ \\
\hline SARS- CoV2 & $\begin{array}{l}\text { Novel Coronavirus Disease } \\
\text { (COVID-19) }\end{array}$ & $\begin{array}{l}\text { The New Coronavirus Disease (COVID-19) is a disease caused by a } \\
\text { virus first identified on January 13, } 2020 \text { as a result of research } \\
\text { conducted in a group of patients who developed respiratory } \\
\text { symptoms (fever, cough, shortness of breath) in late December in } \\
\text { Wuhan Province, China. }\end{array}$ \\
\hline
\end{tabular}

Recommended dietary allowance (RDA) of zinc is $8-11(\mathrm{Fe}-$ male/Male) $\mathrm{mg}$ /day (upper intake level threshold $40 \mathrm{mg} /$ day) in the case of adults. However, in the long term, high zinc intake may disrupt the copper balance, so an intake of $\leq 25$ $\mathrm{mg}$ /day is recommended (Alexander et al., 2020). Meat and seafood are major sources of dietary zinc, while the zinc in plant-based diets containing folate, phytic acid and some phytochemicals which are potent inhibitors of $\mathrm{Zn}$ absorption and is less available. On the other hand, legume seeds also are considered as the important sources of zinc.

In summary, products such as seafood (cooked oysters), beef and lamb (cooked), fish, poultry, pork (cooked) from the animal food group, spinach, pumpkin, white mushrooms (cooked), and strawberries, as well as products from the cereal and 
legume group such as leavened whole grains, wheat germ (toasted) and beans (cooked chickpeas) can be cited as the main zinc source.

\section{Iron (Fe)}

Main function of the iron in the human body is to carry oxygen from the lungs to the tissues, therefore; iron deficiency can impair immunity and be a risk factor for the development of recurrent acute respiratory tract infections (Jayaweera, Reyes, \& Joseph, 2019). However, iron overload can cause oxidative stress to propagate harmful viral mutations (Zhang \& Liu, 2020). As for studies on iron and viruses, in a study (Zhu et al., 2019), it was determined that iron supplementation reduced dengue virus prevalence and viral load, whereas neutralization of serum iron facilitated dengue virus infection. The reason of this situation is that many viruses also need iron-containing enzymes to complete their replication process. In a different study, Iron supplementation was determined to increase mortality risk among HIV-Infected Patients (Haider et al., 2019). It is therefore noted that iron chelators represent a promising adjunct strategy in the treatment of viral infections, limiting iron by oral intake or venous injection. Iron is essential for a central component of the immune system, the differentiation and growth of epithelial tissue and the neutrophils (a type of white blood cells) to produce a reactive oxygen species to kill pathogens. RDA of iron is $8-18$ (Female/Male) $\mathrm{mg}$ /day in the case of adults (Gombart et al., 2020). Iron from animal sources is so readily absorbed than from plants, many of these sources such as lean beef, oysters, chicken and turkey are recommended. Conversely, it has been indicated that viral infections that disrupt liver function can cause changes in iron homeostasis, and in this case iron overload can exacerbate chronic viral disease. In particular, Iron overload during infection with human immunodeficiency virus (HIV), hepatitis B virus (HBV), or hepatitis $\mathrm{C}$ virus $(\mathrm{HCV})$ is associated with increased disease progression (Schmidt, 2020). In a study, as individuals with severe and very severe COVID-19 exhibited increased serum ferritin level, it has been proposed iron depletion therapy as a novel therapeutic approach in the COVID-19 pandemic (Perricone et al., 2020). Of course, the negative situation here is not the iron intake with food, but the consequences of excessive iron loading.

\section{Selenium (Se)}

Selenium is an essential mineral, meaning it must be obtained through diet. Dietary selenium deficiency is a significant factor in immunity. The oxidative stress in the host can alter a viral genome, increase the pathology of an influenza virus infection and also augmented virulence in humans has been linked to nutrient deficiencies, including that of the micronutrient selenium (Seale, Torres, Berry, \& Pitts, 2020). The immune response to live bivalent infectious bronchitis coronavirus vaccine could be stimulated by synergistic effect of selenium with ginseng stem-leaf saponins(Harthill, 2011). Besides, there is an opinion that swine flu, avian flu, and SARS (another coronavirus) developed in selenium-deficient regions of China, Ebola, HIV, in selenium-deficient regions of Sub-Saharan Africa (Harthill, 2011). Selenium shows antiviral properties in the form of sodium selenite. This component can oxidize the thiol groups in the virus protein disulfide isomerase, rendering the virus unable to penetrate the healthy cell membrane (Kieliszek \& Lipinski, 2020). There have been various studies in the literature about the effect of selenium on viral diseases.

Recommended dietary allowance of selenium is $55 \mu \mathrm{g} /$ day in the case of adults(Gombart et al., 2020). However, a total long-term intake of selenium from food and supplements $\leq$ $300 \mu \mathrm{g} /$ day is recommended, as higher intakes may be associated with toxicity. There are a lot of foods with high levels of selenium including meat, chicken, fish and eggs are protein-rich foods (Klapec et al., 2004).

\section{Copper (Cu)}

Copper (II) is a co-factor in the active of superoxide dismutase, which involved in the body antioxidant defenses and the functions of critical immune cells such as T helper cells, B cells, neutrophils natural killer (NK) cells, and macrophages (Raha, Mallick, Basak, \& Duttaroy, 2020). In a study, it was determined that a $\mathrm{Cu}$-complex compound had antiviral effect to DENV-2 in Vero cells which are monkey kidney epithelial cell (Sucipto \& Martak, 2020). Sucipto and Martakalso reported that Copper (II) dihydrate exhibited a disruption effect on dengue virus replication, DENV-2, in vivo study (Sucipto \& Martak, 2020). Copper $(\mathrm{Cu})$ can significantly reduce the infectious viruses such as bronchitis virus, poliovirus, human immunodeficiency virus type 1(HIV-1).

The current United States Recommended Daily Intake is 0.9 $\mathrm{mg}$ (Raha et al., 2020). The richest dietary copper sources include shellfish, seeds and nuts, organ meats, wheat-bran cereals, whole-grain products, and chocolate. 


\section{Magnesium (Mg)}

$\mathrm{Mg}$ extremely important antioxidant nutrient: human body can't make it and must get from outside. Research showing magnesium powerfully supports the immune system. In humans, $\mathrm{Mg}$ the second most abundant intracellular cation after potassium, plays several roles, involves in $>600$ enzymatic reactions in the body, and regulating basic roles such as neuromuscular conduction, muscle contraction, myocardial contraction, blood sugar control, and blood pressure, maintaining tissue integrity and cellular functions, as $\mathrm{Mg}$ plays a significant role in immunity and metabolism maybe contributing to the exaggerated immune and inflammatory responses exhibited by COVID-19 patients (Wallace, 2020). People with decreasing levels of magnesium especially elderly people have correlated with the increase of proinflammatory cytokines (IL-6, THF-x) that's means more free radical damage and inflammatory responses.

The RDAs for $\mathrm{Mg}$ are $300 \mathrm{mg}$ for young women and $350 \mathrm{mg}$ for young men $(4.5-5 \mathrm{mg} / \mathrm{kg} /$ day). Magnesium is widely distributed in green leafy vegetables, such as spinach, legumes, nuts, seeds, and whole grains, mineral, and bottled waters can also be sources of magnesium (Azoulay, Garzon, \& Eisenberg, 2001).

\section{Vitamin D}

Vitamin D is known to induce antimicrobial peptide LL-37, which has antiviral, -bacterial and -fungal effects. Several articles on the effects of vitamin D on either prevention or treatment of COVID-19 are being published as we navigate this new pandemic. According to various studies, calcitriol an active form of vitamin $\mathrm{D}$ is activated by ultraviolet radiations, it was determined that the calcitriol lead a rise in the production of antiviral peptidase(Gombart et al., 2020). In another study (Jaratsittisin et al., 2020), it was suggested that vitamin D receptor agonists (VDR) was an effective anti-DENV agents. In different studies, it was shown that vitamin D is significantly associated with virus replication in chronic HBV infection, and that insufficient vitamin D levels most likely fail to suppress hepatitis B Virus (HBV) replication and contribute to poor clinical courses (Hoan et al., 2016). Angiotensin-converting enzyme-2 (ACE-2) is a type I integral membrane protein and the host cell receptor responsible for mediating virus entry into the cell through binding with spike (S) protein(Zhang, Penninger, Li, Zhong, \& Slutsky, 2020). It is known that the active form of vitamin $\mathrm{D}$ can induce the expression of ACE-2. Taking this information together it seems rational to consider a potential role for vitamin $\mathrm{D}$ against SARS-Cov-2. The richest dietary vitamin D sources include fish, mushroom, and fortified dairy products.

\section{Vitamin $K$}

Vitamin K plays role on coagulation in which is an intricate balance between clot promoting and dissolving processes. Vitamin $\mathrm{K}$ is also a cofactor of anticoagulant protein $\mathrm{S}$. There are limited studies on the viral effect of vitamin $\mathrm{K}$ (Janssen et al., 2020). In a study (Dofferhoff et al., 2020), it was determined that pneumonia-induced extrahepatic vitamin K depletion leading to accelerated elastic fiber damage and thrombosis in severe COVID-19 due to impaired activation of MGP and endothelial protein S, respectively. In other study (Walk et al., 2020), it was hypothesized that vitamin D might have both favorable anti-inflammatory and unfavorable pro-calcification effects during COVID-19 and that vitamin K might compensate for the latter. Many studies are needed for the effect on COVID-19 of this vitamin.

\section{B-Vitamins}

B vitamins are water-soluble vitamins and plays an important role as a part of coenzymes and in the energy metabolism of all cells. The different roles of vitamin B could be chosen as a potential treatment options for the treatment of COVID-19 (Zhang \& Liu, 2020). Vitamin B1 (thiamine) is recognized as thiamin and anurine and also the first type of vitamin B that has been identified. In HIV patients, it is essential to test the extent of Vitamin B1, as it can play beneficial roles in these cases. Niacin (B3) showed a significantly anti-inflammatory effect during ventilator induced lung injury (Zhang \& Liu, 2020). Vitamin B6 (pyridoxine) participates in more than 100 enzyme reactions also play important role in production of $\mathrm{T}$ cells and interleukins (Qian, Shen, Zhang, \& Jing, 2017).Vitamin B-12 is a crucial B vitamin with a vital role in the immune system, it is needed for the production of white blood cells. It is also act as an immunomodulatory factor to maintain the normal function of macrophages (Bourbour et al., 2020). The predominant sources of B vitamins are grain and cereal-grain food, seeds and normal intestinal microbiome.

\section{Vitamin A}

Vitamin $\mathrm{A}$ is a fat-soluble vitamin to be recognized and $\beta$ carotene is its plant-derived precursor. Vitamin-A supplementation was associated with reduced mortality in patients with Ebola Virus disease during the West African outbreak (Aluisio et al., 2019). In other study, it was determined that Vitamin-A supplementation improves linear and ponderal growth in infants who are infected with HIV (Villamor et al., 2002). A studies reported that vitamin A has several mechanisms contributes to the phagocytic and oxidative activities of macrophages, regulate the number and function of NK cells (Natural killer cells; a type of lymphocyte cells) 
(Bourbour et al., 2020; Gombart et al., 2020). In a study, it had reported that diets with low vitamin A may reduce the effectiveness of inactivated bovine coronavirus vaccines and increase the susceptibility to infectious diseases (Jee et al., 2013). There are some foods with high amount of vitamin A include liver, potato and carrot.

\section{Probiotics}

Evidence for antiviral activity of probiotic strains against common respiratory viruses, including influenza, rhinovirus, and respiratory syncytial virus comes from clinical and experimental studies (Turner et al., 2017). Several probiotics have been reported to possess an immunomodulatory ability and protect from virus infections by enhancing cytokine antiviral responses in respiratory and immune cells and in the intestinal mucosa (Biliavska, Pankivska, Povnitsa, \& Zagorodnya, 2019). In a study, it was detected that the strains of Lactobacillus paracasei, Lactobacillus rhamnosus, as well as Lactobacillus plantarum could interact with the envelope of vesicular stomatitis virus (VSV) (Botić, Klingberg, Weingartl, \& Cencič, 2007). And, in a different study, it was determined that Lactobacillus gasseri exhibited antiviral activity against respiratory syncytial virus (RSV) (Infusino et al., 2020). Besides, it is known that orally ingested probiotics strains of Lactobacillus and Bifidobacterium species have enhanced cytokine production in the lungs or serum against viruses (Lehtoranta et al., 2014).

\section{Bioactive Peptides}

Recently, bioactive peptides have gained much attention because of their numerous health beneficial effects and exhibit various biological activities such as antioxidant and anti-human immunodeficiency virus. Matemu et al. (2011) found that covalent attachment of saturated fatty acids to 7S-peptides improve their antiviral activity against feline calicivirus (FCV) on the Crandell-Reese feline kidney (CRFK) cells as well as increase in surface properties of generated lipopeptides. An experiment study suggests that ZY13, one of the peptidic analogs of cathelicidin-BF (BF-30) efficiently restrict ZIKV infection (Xing et al., 2020).

Carnosine, an endogenous dipeptide consisting of beta-alanine and L-histidine, and anserine, a methylated form of carnosine is found in cells such as skeletal, cardiac, and smooth muscle cells. Therefore, they are found in protein rich foods like red meat, chicken, seafood. The anserine/carnosine in some studies, it was determined that dietary intake of acerine/carnosine supports the immunological defense against infections caused by bacteria, fungi, parasites and/ or viruses by increasing the functions of some immune cells (monocytes and macrophages) (Wu, 2020).

\section{Polyunsaturated Fatty Acids (PUFAs)}

Polyunsaturated fatty acids (PUFAs) are fatty acids that contain more than one double bond in their backbone. PUFAs are also known to have anti-viral actions besides many positive effects on health (Das, 2008). For example, it was determined that both cis-linoleic acid (18:2, omega-6) and arachidonic acid $(20: 4, \omega-6)$ could inactivate animal herpes, influenza, Sendai, and Sindbis virus within minutes of contact (Kohn et al., 1980). Also, in a study (Leu et al., 2004), it was determined that strong synergistic anti-HCV effect was observed when the arachidonic acid was combined with IFN- $\alpha$ (interferon- $\alpha$ ) which is a substance found naturally in the body in very small quantities and defends the body against viruses. On the other hand, $\alpha$ - linolenic acid (18:3, omega-3) fatty acid is a safe, effective, and low-cost strategy to help support optimal immune function. Polyunsaturated fatty acids such as the omega- 3 characterized by boosting the immune system by improving B cells (B-lymphocyte) activity, reducing cytokines, lowering the inflammatory eicosanoids, and increasing phagocytosis. It is also could noticeably rarefy influenza virus replication via the RNA export machinery (Bourbour et al., 2020).

It has been considered that the anti-HCV effect of PUFAs is due to the formation of significant amounts of lipid peroxides. Lymphocytes and macrophages contain significant amounts of PUFAs and release them on appropriate stimulation. This action is predicted to be similar to the fact that PUFAs stimulate NADPH-dependent superoxide production by macrophages, neutrophils and lymphocytes that has bactericidal action (Das, 2008). Of polyunsaturated fatty acids; omega-3 ( $\omega$ 3 ) fatty acid is found in fish and seafood.

\section{Some Functional Foods with Antiviral Properties}

Diet management should be considered in terms of improvement Immunity and the use of antiviral properties for a small number of nutrients. General recommendations for healthy adults can generally be described as rich in plant foods, including fresh fruits and vegetables, soybeans and nuts, good sources of antioxidants, omega-3 fatty acids, lower in saturated fats/trans fats and animal proteins (Table 2).

Citrus is one of the nature's best and easily available source of vitamin $\mathrm{C}$, flavonoid, fiber, antioxidant, anti-tumour, cardio-protective and neuro-protective agent what makes them significant is their immune boosting potential, reduce inflammation, improve gastrointestinal function and health. Citrus fruits play an important role in preventing conditions like diabetes, cancer, neurological disease. Apples are a good source of fiber and vitamin C. They also contain polyphenols, which may have numerous health benefits. 
Table 2. Some foods and their components associated with antiviral activity

\begin{tabular}{lll}
\hline Food item & Components associated with antiviral activity & Reference \\
\hline Almonds, Peanuts & Vitamin E levels antiviral activities & (Makau et al., 2018) \\
\hline Camellia sinensis & Flavonoids, polyphenols, antioxidants & (Suchitra \& Parthasarathy, 2020) \\
\hline Broccoli & Sulforaphane, Antiviral effects & (Antonenko et al., 2013) \\
\hline Garlic extracts & Organosulfur, Antiviral activity & (Suchitra \& Parthasarathy, 2020) \\
\hline Curcumin & Reduced the inflammatory cytokines & (Hewlings \& Kalman, 2017) \\
\hline Paprika & vitamin C and vitamin E & (M. H. Gnayfeed, Daood, Biacs, \& Alcaraz, 2001) \\
\hline Zingiber officinale & Antiviral activity (H1N1, influenza A and HRSV) & (Chang et al., 2013) \\
\hline Leafy vegetables & Beta carotene, Antioxidant, elevating leucocytes. & (Grune et al., 2010) \\
\hline Coconut water & Vitamin $\mathrm{B}_{2}, \mathrm{~B}_{3}, \mathrm{~B}_{1}$ and B, antiviral activity & (Chauhan et al., 2014) \\
\hline Aromatic plants & Polyphenolics & (Christaki, Bonos, Giannenas, \& Florou-Paneri, \\
\hline Spinach & & 2012) \\
\hline Kiwifruit & Carotenoids (Lutein, $\alpha$-carotene) & (Carbonell-Capella, Buniowska, Barba, Esteve, \& \\
\hline Banana & Antioxidant & Frígola, 2014) \\
\hline Onion & Phenolics, carotenoids, biogenic amines, phytosterols & (Kaur, Purewal, Sandhu, \& Kaur, 2019) \\
\hline Spirulina extract & Sulpholipids, bioactive proteins (Cyanovirin-N) & (Sharma, 2019) \\
\hline
\end{tabular}

Nuts and seeds such as almonds and peanuts have high vitamin E levels. Also, they include minerals such as the Zn, Se, $\mathrm{Cu}$. In a study, it was determined that almonds and the peanut skin had significant antiviral activities (Makau, Watanabe, Mohammed, \& Nishida, 2018).

Green tea (Camellia sinensis) contains a group of flavonoids called catechins have shown to be effective in inhibiting viral infections. This advantageous effect has been ascribed to the existence of high amounts of polyphenols, which are vigorous antioxidants (Chacko, Thambi, Kuttan, \& Nishigaki, 2010).

The sulforaphane, a chemical found in vegetable such as Broccoli (Brassica oleracea var. İtalica), other cruciferous vegetables have claimed to turn on the antioxidant genes and enzymes in particular immune cells. Also, it is known that Broccoli has antiviral effects against influenza viruses (Antonenko et al., 2013).

Garlic (Allium sativum) extracts has been recognized to have organosulfur compounds like allicin, diallyl trisulfide and ajoene are main chemicals, which impart antiviral property to garlic, showed the antiviral activity against HIV, herpes, cytomegalovirus and the flu viruses.
Curcumin (Curcuma longa) is a bright yellow chemical produced by Curcuma longa plants and belonging to the ginger family is recognized to be significantly reduced the inflammatory cytokines (Hewlings \& Kalman, 2017). In some studies, conducted related with action of curcumin on viruses, it was determined that curcumin demonstrated various protective and/or inhibitory activities such as inhibition of viral replication, inhibition of viral entry, degradation of viral Tat protein and interaction with VP30 against viruses such as the RVFV, the HCV, the EV, influenza A virus (IAV) and bovine herpesvirus 1 (BHV 1) (Mathew \& Hsu, 2018). The ginger (Zingiber officinale) and its extracts demonstrated to have antiviral activity (H1N1, influenza A and HRSV) and inhibition of viral replication by promoting the function of the immune systems (Chang, Wang, Yeh, Shieh, \& Chiang, 2013).

Olive based products (olive oil, olive leaves) include oleuropein, hydroxytyrosol, elenolic acid, vitamin E components. It was determined that these components were reduced the upper respiratory infection with antioxidative property of oleanolic acid in oleuropein against especially influenza $\mathrm{A}$ and B, parainfluenza 1, 2, and 3 viruses, and herpes (Somerville, Moore, \& Braakhuis, 2019). 
Table 3. Some nutrients and microorganisms effective on viral diseases and recommended daily intakes (RDI) of them.

\begin{tabular}{|c|c|c|c|}
\hline $\begin{array}{c}\text { Some foods or microorganisms } \\
\text { effective on viral diseases }\end{array}$ & Food and concentration in this food & $\begin{array}{l}\text { Recommended Dietary Allowance (RDA) } \\
\text { (in adult individuals) }\end{array}$ & Reference \\
\hline Zinc (Zn) & $\begin{array}{l}\text { Lean red meat, whole-grain cereals, } \\
\text { pulses, and legumes }(2.5-5 \mathrm{mg} / 100 \mathrm{~g})\end{array}$ & $8 \mathrm{mg} /$ day for women and $11 \mathrm{mg} /$ day for men. & (Institute of Medicine, 2001) \\
\hline Iron (Fe) & $\begin{array}{l}\text { Beef, variety meats and by-products, } \\
\text { spleen, cooked, braised ( } 33.46 \mathrm{mg} / \\
100 \mathrm{~mL})\end{array}$ & $18 \mathrm{mg} /$ day for women and $8 \mathrm{mg} /$ day for men. & (NIHa, 2021) \\
\hline Selenium (Se) & Brazil Nuts $(1.92 \mathrm{mg} / 100 \mathrm{~g})$ & $55 \mu \mathrm{g} /$ day for women and men & $\begin{array}{l}\text { (Institute of Medicine,2000; } \\
\text { Nutrition Facts for } \\
\text { Brazilnuts, 2021) }\end{array}$ \\
\hline Copper (Cu) & $\begin{array}{l}\text { Tempeh }(0.9 \mathrm{mg} / \text { cup }) \text { Beef, liver, pan } \\
\text { fried }(12.4 \mathrm{mg} / 100 \mathrm{~mL})\end{array}$ & $900 \mu \mathrm{g} /$ day for women and men & $\begin{array}{l}\text { (Institute of Medicine, 2000; } \\
\text { NFT, 2021) }\end{array}$ \\
\hline Magnesium (Mg) & Pumpkin seeds, roasted & $\begin{array}{l}310 \mathrm{mg} / \text { day for women, } \\
420 \mathrm{mg} / \text { day for men }\end{array}$ & (Food Data Central, 2021) \\
\hline Vitamin D & Fish salmon (685 IU/100 g) & $600 \mathrm{IU} /$ day for women and men & (Food Data Central, 2021) \\
\hline Vitamin K & $\begin{array}{l}\text { Spinach and broccoli (raw, } 498 \text { and } \\
307 \mu \mathrm{g} / 100 \mathrm{~g} \text { wet weight, respectively) }\end{array}$ & $1 \mathrm{mg} / \mathrm{kg}$ day & $\begin{array}{l}\text { (Booth \& Suttie, 1998; } \\
\text { Kamao et al., 2007) }\end{array}$ \\
\hline Vitamin A & Beef Liver (16814 IU) & $\begin{array}{l}600 \mu \mathrm{g} / \text { day for women } \\
700 \mu \mathrm{g} / \text { day for men. }\end{array}$ & $\begin{array}{l}\text { (Food Data Central, 2021; } \\
\text { Olson, 1987) }\end{array}$ \\
\hline $\begin{array}{l}\text { B-Vitamins } \\
\text { (B1, B2, B3, B5, B9, B12 etc.) }\end{array}$ & $\begin{array}{l}\text { Whole grain wheat and barley cereal } \\
\text { (B1;1 mg, B2; } 0.117 \mathrm{mg}, \mathrm{B} 3 ; 8.621 \\
\mathrm{mg}, \mathrm{B} 6 ; 0.862 \mathrm{mg} \text { ) }\end{array}$ & $\begin{array}{l}\mathrm{B} 3=35\left(\mathrm{mg} / \text { day }^{*}\right) \\
\text { B6 }=100(\mathrm{mg} / \text { day } *) \\
\text { Folate }(\mathrm{B} 9)=1000\left(\mu \mathrm{g} / \text { day }^{*}\right) \\
\text { B12 }=3.5-2.4(\mu \mathrm{g} / \text { day })\end{array}$ & $\begin{array}{l}\text { (Food Data Central, 2021; } \\
\text { Institute of Medicine, 1998) }\end{array}$ \\
\hline Probiotic microorganisms & $\begin{array}{l}\text { Yogurts, Cheeses, Beverages, Ice } \\
\text { Creams }\end{array}$ & n.d. $* *$ & (Granato et al., 2010) \\
\hline Bioactive peptides & $\begin{array}{l}\text { Milk, Whey, Soyabean, fruits, } \\
\text { vegetables, and grains }\end{array}$ & n.d. & $\begin{array}{l}\text { (Korhonen \& Pihlanto, 2003; } \\
\text { Liu, 2013) }\end{array}$ \\
\hline $\begin{array}{l}\text { Polyunsaturated fatty acids } \\
\text { (PUFAs; } \alpha \text {-linolenic acid: ALA, } \\
\text { linoleic acid: LA, Docosa- } \\
\text { hexaenoic acid: DHA, Eicosa- } \\
\text { pentaenoic acid: EPA, etc.) }\end{array}$ & $\begin{array}{l}\text { Soybean oil (MUFAs; } 22.783 \mathrm{~g} / 100 \mathrm{~g} \text {, } \\
\text { PUFAs } 57.74 \mathrm{~g} / 100 \mathrm{~g}) \text {; Salmon }(1.8 \\
\text { g/100 g); Omega-3). Fish, mackerel, } \\
\text { salted ((EPA)1.619 g/100g, (DPA } \\
0.391 \mathrm{~g} / 100 \mathrm{~g},(\mathrm{DHA}) 2.965 \mathrm{~g} / 100 \mathrm{~g})\end{array}$ & $1.1 \mathrm{~g} /$ day for women and $1.6 \mathrm{~g} /$ day for men. & $\begin{array}{l}\text { (Food Data Central, 2021; } \\
\text { NIH, 2021b) }\end{array}$ \\
\hline
\end{tabular}

The yellow/orange pigment beta carotene that found in green leafy vegetables, sweet potatoes, and carrots like all carotenoids, is an antioxidant can reduce inflammation and boost immune function by elevating leucocytes in the body (Grune et al., 2010). Coconut water is rich in vitamins like B2, B3, B1 and B9 along with immune stimulating properties to fight viral infections like flu (Chauhan, Archana, Singh, Raju, \& Bawa, 2014).

The onion (Allium cepa L.), contains organosulfur compounds like quercetin and allicin are associated with hinder virus attachment to host cell, alter transcription and translation of viral genome in host cell and also affect viral assembly (Sharma, 2019). Spirulina is a dietary supplement. It is a freefloating cyanobacterium, which has $70 \%$ protein content and is rich in phenolic acids, essential fatty acids, sulfated polysaccharides, and vitamin B12. In literature, it is found some studies related with the antiviral activity of Spirulina against viruses (Joseph, T, Ajay, Das, \& Raj, 2020).

Some nutrients and microorganisms effective on viral diseases, and the recommended daily intakes (RDI) of them were given in Table 3.

The yellow/orange pigment beta carotene that found in green leafy vegetables, sweet potatoes, and carrots like all carotenoids, is an antioxidant can reduce inflammation and boost immune function by elevating leucocytes in the body (Grune et al., 2010). Coconut water is rich in vitamins like B2, B3, B1 and B9 along with immune stimulating properties to fight viral infections like flu (Chauhan, Archana, Singh, Raju, \& Bawa, 2014).

The onion (Allium cepa L.), contains organosulfur compounds like quercetin and allicin are associated with hinder 
virus attachment to host cell, alter transcription and translation of viral genome in host cell and also affect viral assembly (Sharma, 2019). Spirulina is a dietary supplement. It is a freefloating cyanobacterium, which has $70 \%$ protein content and is rich in phenolic acids, essential fatty acids, sulfated polysaccharides, and vitamin B12. In literature, it is found some studies related with the antiviral activity of Spirulina against viruses (Joseph, T, Ajay, Das, \& Raj, 2020).
Some nutrients and microorganisms effective on viral diseases, and the recommended daily intakes (RDI) of them were given in Table 3 .

Furthermore, some foods with immune-enhancing properties and their relationship with immune system cells are given in Figure 1.

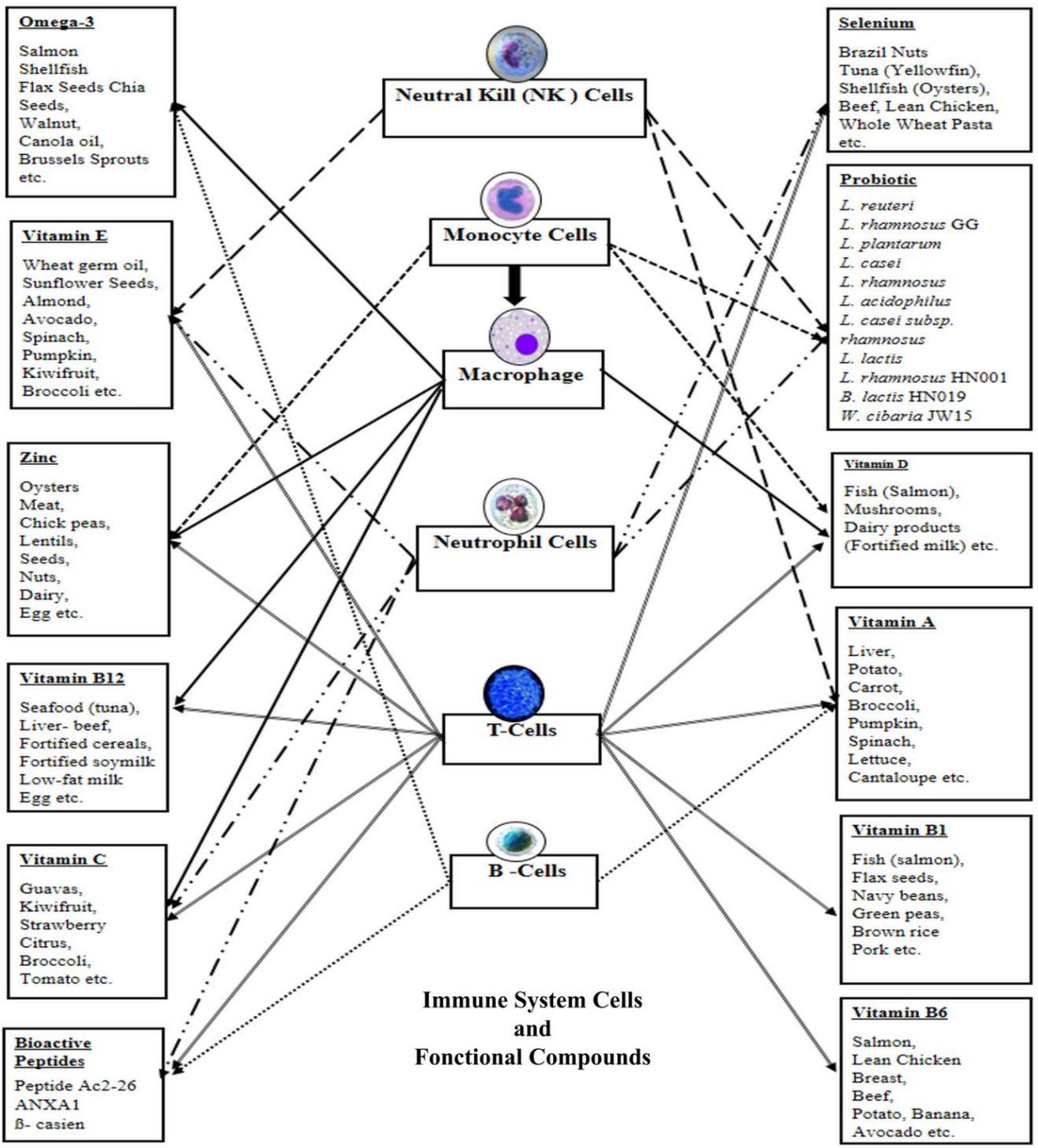

Figure 1. Some foods with immune-enhancing properties (Alkhatib et al., 2020; Bourbour et al., 2020) 


\section{Conclusion}

This study provides a brief overview of the immune-enhancing and antiviral properties of some bioactive ingredients (especially micronutrients) in foods on Covid-19 and other viral infections. It is a fact that a balanced diet supported by appropriate foods, functional foods and antioxidants is needed in the prevention and treatment of viral infections. The information mentioned for nutritional interventions generates dietary hypotheses that can be applied for protection from COVID-19 and other viral diseases. Thus, further studies are needed to clarify the role of COVID-19 and viral diseases with strong recommendations.

\section{Compliance with Ethical Standard}

Conflict of interests: The authors declare that for this article they have no actual, potential or perceived the conflict of interests.

Ethics committee approval: The authors declare that this study does not require ethical permission.

Funding disclosure: -

Acknowledgments: -

Disclosure: A small part of this study was presented as a summary with oral presentation at "II. International Agriculture, Biology \& Life Sciences Conference (E-AGBIL 2020, September 1-3, Edirne/ Turkey)". Only the summary part of it has been published in the congress book.

\section{References}

Alexander, J., Tinkov, A., Strand, T. A., Alehagen, U., Skalny, A., Aaseth, J. (2020). Early nutritional interventions with zinc, selenium and vitamin D for raising anti-viral resistance against progressive COVID-19. Nutrients, 12(8), 2358. https://doi.org/10.3390/nu12082358

Alkhatib, A. L., Kreniske, J., Zifodya, J. S., Fonseca, V., Tahboub, M., Khatib, J., ... Bojanowski, C. M. (2020). BMI is associated with Coronavirus disease 2019 Intensive Care Unit Admission in African Americans. Obesity, 28(10), 1798-1801.

https://doi.org/10.1002/oby.22937

Aluisio, A. R., Perera, S. M., Yam, D., Garbern, S., Peters, J. L., Abel, L., ... Levine, A. C. (2019). Vitamin A supplementation was associated with reduced mortality in patients with Ebola virus disease during the West African outbreak. The Journal of Nutrition, 149(10), 1757-1765.

https://doi.org/10.1093/jn/nxz142
Antonenko, Y.N., Khailova, L.S., Knorre, D.A., Markova, O.V., Rokitskaya, T.I., Ilyasova, T.M., ... Skulachev, V.P. (2013). Penetrating cations enhance uncoupling activity of anionic protonophores in mitochondria. PLOS ONE, 8(4), e61902.

https://doi.org/10.1371/journal.pone.0061902

Azoulay, A., Garzon, P., Eisenberg, M.J. (2001). Comparison of the mineral content of tap water and bottled waters. Journal of General Internal Medicine, 16(3), 168-175. https://doi.org/10.1111/j.1525-1497.2001.04189.x

Biliavska, L., Pankivska, Y., Povnitsa, O., Zagorodnya, S. (2019). Antiviral activity of exopolysaccharides produced by lactic acid bacteria of the genera Pediococcus, Leuconostoc and Lactobacillus against human adenovirus type 5. Medicina, 55(9), 519.

https://doi.org/10.3390/medicina55090519

Bloom, D.E., Cadarette, D. (2019). Infectious disease threats in the twenty-first century: Strengthening the global response. Frontiers in Immunology, 10(549).

https://doi.org/10.3389/fimmu.2019.00549

Booth, S.L., Suttie, J.W. (1998). Dietary intake and adequacy of vitamin K. The Journal of Nutrition, 128(5), 785-788. https://doi.org/10.1093/jn/128.5.785

Botić, T., Klingberg, T.D., Weingartl, H., Cencič, A. (2007). A novel eukaryotic cell culture model to study antiviral activity of potential probiotic bacteria. International Journal of Food Microbiology, 115(2), 227-234.

https://doi.org/10.1016/j.ijfoodmicro.2006.10.044

Bourbour, F., Dahka, S.M., Gholamalizadeh, M., Akbari, M.E., Shadnoush, M., Haghighi, M., ... Doaei, S. (2020). Nutrients in prevention, treatment, and management of viral infections; special focus on Coronavirus. Archives of Physiology and Biochemistry,

https://doi.org/10.1080/13813455.2020.1791188

Carbonell-Capella, J.M., Buniowska, M., Barba, F.J., Esteve, M.J., Frígola, A. (2014). Analytical methods for determining bioavailability and bioaccessibility of bioactive compounds from fruits and vegetables: A review. Comprehensive Reviews in Food Science and Food Safety, 13(2), 155-171. https://doi.org/10.1111/1541-4337.12049

CDC (2020). Rift Valley Fever | CDC. https://www.cdc.gov/vhf/rvf/index.html 
(accessed 20.08.2020)

Chacko, S.M., Thambi, P.T., Kuttan, R., Nishigaki, I. (2010). Beneficial effects of green tea: A literature review. Chinese Medicine, 5(1), 13.

https://doi.org/10.1186/1749-8546-5-13

Chang, J.S., Wang, K.C., Yeh, C.F., Shieh, D.E., Chiang, L.C. (2013). Fresh ginger (Zingiber officinale) has anti-viral activity against human respiratory syncytial virus in human respiratory tract cell lines. Journal of Ethnopharmacology, 145(1), 146-151.

https://doi.org/10.1016/j.jep.2012.10.043

Chauhan, O.P., Archana, B.S., Singh, A., Raju, P.S., Bawa, A.S. (2014). A refreshing beverage from mature coconut water blended with lemon juice. Journal of Food Science and Technology, 51(11), 3355-3361.

https://doi.org/10.1007/s13197-012-0825-6

Chiu, H.-P., Chiu, H., Yang, C.-F., Lee, Y.-L., Chiu, F.-L., Kuo, H.-C., ... Lin, Y.-L. (2018). Inhibition of Japanese encephalitis virus infection by the host zinc-finger antiviral protein. PLOS Pathogens, 14(7), e1007166.

https://doi.org/10.1371/journal.ppat.1007166

Christaki, E., Bonos, E., Giannenas, I.,, Florou-Paneri, P. (2012). Aromatic Plants as a Source of Bioactive Compounds. Agriculture, 2(3), 228-243.

https://doi.org/10.3390/agriculture2030228

Das, U.N. (2008). Can essential fatty acids reduce the burden of disease (s)?. Lipids in Health and Disease, 7(1), 1-5.

https://doi.org/10.1186/1476-511X-7-9

Dofferhoff, A.S., Piscaer, I., Schurgers, L.J., Visser, M.P., van den Ouweland, J.M., de Jong, P.A., ... Janssen, R. (2020). Reduced vitamin K status as a potentially modifiable risk factor of severe Coronavirus disease 2019. Clinical Infectious Diseases, 2.

https://doi.org/10.1093/cid/ciaa1258

Food Data Central (2021). Retrieved February 21, 2021, from https://fdc.nal.usda.gov/ (accessed 21.02.2021)

Gnayfeed, M.H., Daood, H.G., Biacs, P.A., Alcaraz, C.F. (2001). Content of bioactive compounds in pungent spice red pepper (paprika) as affected by ripening and genotype. Journal of the Science of Food and Agriculture, 81(15), 15801585 .

https://doi.org/10.1002/jsfa.982
Granato, D., Branco, G.F., Cruz, A.G., Faria, J. de A.F., Shah, N.P. (2010). Probiotic dairy products as functional foods. Comprehensive Reviews in Food Science and Food Safety, 9(5), 455-470.

https://doi.org/10.1111/j.1541-4337.2010.00120.x

Gombart, A.F., Pierre, A., Maggini, S. (2020). A review of micronutrients and the immune system-working in harmony to reduce the risk of infection. Nutrients, 12(1), 236.

https://doi.org/10.3390/nu12010236

Grune, T., Lietz, G., Palou, A., Ross, A.C., Stahl, W., Tang, G., ... Biesalski, H.K. (2010). $\beta$-Carotene is an important vitamin A source for humans. The Journal of Nutrition, 140(12), 2268S-2285S.

https://doi.org/10.3945/jn.109.119024

Haider, B.A., Spiegelman, D., Hertzmark, E., Sando, D., Duggan, C., Makubi, A., ... Fawzi, W.W. (2019). Anemia, iron deficiency, and iron supplementation in relation to mortality among HIV-infected patients receiving highly active antiretroviral therapy in Tanzania. American Journal of Tropical Medicine and Hygiene, 100(6), 1512-1520.

https://doi.org/10.4269/ajtmh.18-0096

Harthill, M. (2011). Review: Micronutrient selenium deficiency influences evolution of some viral infectious diseases. Biological Trace Element Research, 143(3), 1325-1336.

https://doi.org/10.1007/s12011-011-8977-1

Herrero-Uribe, L. (2011). Viruses, definitions and reality. Revista de Biología Tropical, 59(3), 993-998.

https://doi.org/10.15517/rbt.v0i0.3372

Hewlings, S., Kalman, D. (2017). Curcumin: A review of its effects on human health. Foods, 6(10), 92.

https://doi.org/10.3390/foods6100092

Hoan, N.X., Khuyen, N., Binh, M.T., Giang, D.P., Van Tong, H., Hoan, P.Q., ... Song, L.H. (2016). Association of vitamin D deficiency with hepatitis B virus-Related liver diseases. BMC Infectious Diseases, 16(1), 507.

https://doi.org/10.1186/s12879-016-1836-0

Institute of Medicine (US) (1998). Dietary Reference Intakes for Thiamin, Riboflavin, Niacin, Vitamin B6, Folate, Vitamin B12, Pantothenic Acid, Biotin, and Choline. In Dietary Reference Intakes for Thiamin, Riboflavin, Niacin, Vitamin B6, Folate, Vitamin B12, Pantothenic Acid, Biotin, and Choline. National Academies Press (US). 
https://www.ncbi.nlm.nih.gov/books/NBK114296/ (accessed 21.02.2021)

Institute of Medicine (US) Panel on Dietary Antioxidants and RelatedInstitute of Medicine (US) Panel on Dietary Antioxidants and Related. (2000). Food and Nutrition Board, Institute of Medicine-National Academy of Sciences Dietary Reference Intakes: Recommended Intakes for Individuals. In Dietary Reference Intakes for Vitamin C, Vitamin E, Selenium, and Carotenoids. Washington (DC): National Academies Press (US). https://www.ncbi.nlm.nih.gov/books/NBK225472/ (accessed 21.02.2021)

Institute of Medicine (US) Panel on Micronutrients. (2001). Dietary Reference Intakes for Vitamin A, Vitamin K, Arsenic, Boron, Chromium, Copper, Iodine, Iron, Manganese, Molybdenum, Nickel, Silicon, Vanadium, and Zinc. Washington, D.C: National Academies Press (US).

Infusino, F., Marazzato, M., Mancone, M., Fedele, F., Mastroianni, C. M., Severino, P., ... D'ettorre, G. (2020). Diet supplementation, probiotics, and nutraceuticals in SARS-CoV-2 infection: A scoping review. Nutrients, 12(6), 1718.

https://doi.org/10.3390/nu12061718

Janssen, R., Visser, M.P., Dofferhoff, A.S., Vermeer, C., Janssens, W., Walk, J. (2020). Vitamin K metabolism as the potential missing link between lung damage and thromboembolism in Coronavirus disease 2019. British Journal of Nutrition, 1-8.

https://doi.org/10.1017/S0007114520003979

Jaratsittisin, J., Xu, B., Sornjai, W., Weng, Z., Kuadkitkan, A., Li, F., ... Smith, D.R. (2020). Activity of vitamin $\mathrm{D}$ receptor agonists against dengue virus. Scientific Reports, 10(1), 10835.

https://doi.org/10.1038/s41598-020-67783-z

Jayaweera, J.A.A.S., Reyes, M., Joseph, A. (2019). Childhood iron deficiency anemia leads to recurrent respiratory tract infections and gastroenteritis. Scientific Reports, 9(1), 12637.

https://doi.org/10.1038/s41598-019-49122-z

Jee, J., Hoet, A.E., Azevedo, M.P., Vlasova, A.N., Loerch, S.C., Pickworth, C.L., ... Saif, L.J. (2013). Effects of dietary vitamin A content on antibody responses of feedlot calves inoculated intramuscularly with an inactivated bovine coronavirus vaccine. American Journal of Veterinary Research, 74(10), 1353-1362. https://doi.org/10.2460/ajvr.74.10.1353

Joseph, J.,T,K., Ajay, A., Das, V.R.A., Raj, V.S. (2020). Green tea and Spirulina extracts inhibit SARS, MERS, and SARS-2 spike pseudotyped virus entry in vitro. BioRxiv, 2020.06.20.162701.

https://doi.org/10.1101/2020.06.20.162701

Kamao, M., Suhara, Y., Tsugawa, N., Uwano, M., Yamaguchi, N., Uenishi, K., ... Okano, T. (2007). Vitamin K content of foods and dietary vitamin $\mathrm{K}$ intake in Japanese young women. Journal of Nutritional Science and Vitaminology, 53(6), 464-470.

https://doi.org/10.3177/jnsv.53.464

Kaur, P., Purewal, S.S., Sandhu, K.S., Kaur, M. (2019). DNA damage protection: An excellent application of bioactive compounds. Bioresources and Bioprocessing, 6(2), 2019.

https://doi.org/10.1186/s40643-019-0237-9

Kieliszek, M., Lipinski, B. (2020). Selenium supplementation in the prevention of coronavirus infections (COVID-19). Medical Hypotheses, 143, 109878.

https://doi.org/10.1016/j.mehy.2020.109878

Klapec, T., Mandić, M.L., Grgić, J., Primorac, L., Perl, A., Krstanović, V. (2004). Selenium in selected foods grown or purchased in eastern Croatia. Food Chemistry, 85(3), 445452.

https://doi.org/10.1016/j.foodchem.2003.07.031

Kohn, A., Gitelman, J., Inbar, M. (1980). Unsaturated free fatty acids inactivate animal enveloped viruses. Archives of virology, 66(4), 301-307.

https://doi.org/10.1007/BF01320626

Korhonen, H., Pihlanto, A. (2003). Food-derived bioactive peptides-opportunities for designing future foods. Current Pharmaceutical Design, 9(16), 1297-1308.

https://doi.org/10.2174/1381612033454892

Kuhn, J.H., Becker, S., Ebihara, H., Geisbert, T.W., Johnson, K.M., Kawaoka, Y., ... Jahrling, P.B. (2010). Proposal for a revised taxonomy of the family Filoviridae: Classification, names of taxa and viruses, and virus abbreviations. Archives of Virology, 155(12), 2083-2103.

https://doi.org/10.1007/s00705-010-0814-x 
Lehtoranta, L., Pitkäranta, A., Korpela, R. (2014). Probiotics in respiratory virus infections. European Journal of Clinical Microbiology and Infectious Diseases, 33, 1289-1302. https://doi.org/10.1007/s10096-014-2086-y

Leu, G.Z., Lin, T.Y., Hsu, J.T. (2004). Anti-HCV activities of selective polyunsaturated fatty acids. Biochemical and Biophysical Research Communications, 318(1), 275-280.

https://doi.org/10.1016/j.bbrc.2004.04.019

Li, M.M.H., Aguilar, E.G., Michailidis, E., Pabon, J., Park, P., Wu, X., ... Macdonald, M.R. (2019). Characterization of novel splice variants of zinc finger antiviral protein (ZAP) downloaded from. Journal of Virology, 93(18), 715734.

https://doi.org/10.1128/JVI.00715-19

Liu, R.H. (2013). Dietary bioactive compounds and their health implications. Journal of Food Science, (78 Suppl) 1, A18-25.

https://doi.org/10.1111/1750-3841.12101

Makau, J.N., Watanabe, K., Mohammed, M.M.D., Nishida, N. (2018). Antiviral activity of peanut (Arachis hypogaea L.) skin extract against human influenza viruses. Journal of Medicinal Food, 21(8), 777-784.

https://doi.org/10.1089/jmf.2017.4121

Matemu, A.O., Nakamura, K., Kayahara, H., Murasawa, H., Katayama, S., Nakamura, S. (2011). Enhanced antiviral activity of soybean $\beta$-conglycinin-derived peptides by acylation with saturated fatty acids. Journal of Food Science, 76(6), M299-M304.

https://doi.org/10.1111/j.1750-3841.2011.02248.x

Mathew, D., Hsu, W.-L. (2018). Antiviral potential of curcumin. Journal of Functional Foods, 40, 692-699.

https://doi.org/10.1016/j.jff.2017.12.017

NFT, Nutrition Facts for Tempeh, (2021). Myfooddata website:

https://tools.myfooddata.com/nutrition-facts/174272/wt1

(accessed 21.02.2021)

NIH, National Institutes of Health, (2021). Office of Dietary Supplements-Iron. https://ods.od.nih.gov/factsheets/Iron-HealthProfessional/ (accessed 20.02.2021)

NIH, National Institutes of Health, (2021). Office of Dietary Supplements-Omega-3 Fatty Acids.
https://ods.od.nih.gov/factsheets/Omega3FattyAcids-HealthProfessional/ (accessed 21.02.2021)

Nutrition Facts for Brazilnuts. (2021). Myfooddata website: https://tools.myfooddata.com/nutrition-facts/170569/wt (accessed 21.02.2021)

Olson, J.A. (1987). Recommended dietary intakes (RDI) of vitamin A in humans. The American Journal of Clinical Nutrition, 45(4), 704-716.

https://doi.org/10.1093/ajcn/45.4.704

Park, Y.-S., Namiesnik, J., Vearasilp, K., Leontowicz, H., Leontowicz, M., Barasch, D., ... Gorinstein, S. (2014). Bioactive compounds and the antioxidant capacity in new kiwi fruit cultivars. Food Chemistry, 165, 354-361.

https://doi.org/10.1016/j.foodchem.2014.05.114

Pellegrini, M., Roda, M., Lupardi, E., Di Geronimo, N., Giannaccare, G., Schiavi, C. (2020). The impact of COVID19 pandemic on ophthalmological emergency department visits. Acta Ophthalmologica, aos.14489.

https://doi.org/10.1111/aos.14489

Perricone, C., Bartoloni, E., Bursi, R., Cafaro, G., Guidelli, G.M., Shoenfeld, Y., Gerli, R. (2020). COVID-19 as part of the hyperferritinemic syndromes: The role of iron depletion therapy. Immunologic Research, 68, 213-224.

https://doi.org/10.1007/s12026-020-09145-5

Qian, B., Shen, S., Zhang, J., Jing, P. (2017). Effects of Vitamin B6 Deficiency on the Composition and Functional Potential of T Cell Populations. Journal of Immunology Research, 2017,12.

https://doi.org/10.1155/2017/2197975

Raha, S., Mallick, R., Basak, S., Duttaroy, A.K. (2020). Is copper beneficial for COVID-19 patients? Medical Hypotheses, 142, 109814

https://doi.org/10.1016/j.mehy.2020.109814

Read, S.A., Obeid, S., Ahlenstiel, C., Ahlenstiel, G. (2019). The role of zinc in antiviral immunity. Advances in Nutrition, 10, 696-710.

https://doi.org/10.1093/advances/nmz013

Schmidt, S.M. (2020). The role of iron in viral infections. Frontiers in Bioscience, 25(4), 4839.

https://doi.org/10.2741/4839 
Seale, L.A., Torres, D.J., Berry, M.J., Pitts, M.W. (2020). A role for selenium-dependent GPX1 in SARS-CoV-2 virulence. American Journal of Clinical Nutrition, 112, 447-448. https://doi.org/10.1093/ajcn/nqaa177

Sharma, N. (2019). Efficacy of garlic and onion against viru. International Journal of Research in Pharmaceutical Sciences, 10(4), 3578-3586.

https://doi.org/10.26452/ijrps.v10i4.1738

Singh, B., Singh, J.P., Kaur, A., Singh, N. (2016). Bioactive compounds in banana and their associated health benefits-A review. Food Chemistry, 206, 1-11.

https://doi.org/10.1016/j.foodchem.2016.03.033

Somerville, V., Moore, R., Braakhuis, A. (2019). The Effect of Olive Leaf Extract on Upper Respiratory Illness in High School Athletes: A Randomised Control Trial. Nutrients, 11(2), 358.

https://doi.org/10.3390/nu11020358

Suchitra, M.R., Parthasarathy, S. (2020). Nutrition and corona virus: Plan a diet in a pandemic. International Journal of Research in Pharmaceutical Sciences, 11, 110-114.

https://doi.org/10.26452/ijrps.v11iSPL1.2241

Sucipto, T.H., Martak, F. (2020). Inhibition of dengue virus serotype 2 in Vero cells with $[\mathrm{Cu}(2,4,5$-triphenyl-1H-imidazole)2(H2O)2].Cl2. Infectious Disease Reports, 12(S1), 8744.

https://doi.org/10.4081/idr.2020.8744

Turner, R.B., Woodfolk, J.A., Borish, L., Steinke, J.W., Patrie, J.T., Muehling, L.M., ... Lehtinen, M.J. (2017). Effect of probiotic on innate inflammatory response and viral shedding in experimental rhinovirus infection - a randomised controlled trial. Beneficial Microbes, 8(2), 207-215.

https://doi.org/10.3920/BM2016.0160

Villamor, E., Mbise, R., Spiegelman, D., Hertzmark, E., Fataki, M., Peterson, K. E., ... Fawzi, W.W. (2002). Vitamin A supplements ameliorate the adverse effect of HIV-1, Malaria, and Diarrheal infections on child growth. Pediatrics, 109(1), e6-e6.

https://doi.org/10.1542/peds.109.1.e6
Walk, J., Dofferhoff, A.S., van den Ouweland, J.M., van Daal, H., Janssen, R. (2020). Vitamin D-contrary to vitamin K-does not associate with clinical outcome in hospitalized COVID-19 patients. medRxiv.

https://doi.org/10.1101/2020.11.07.20227512

Wallace, T.C. (2020). Combating COVID-19 and building immune resilience: A potential role for magnesium nutrition? Journal of the American College of Nutrition, 39(8), 685-693. https://doi.org/10.1080/07315724.2020.1785971

WHO (2020). Severe Acute Respiratory Syndrome (SARS). https://www.who.int/westernpacific/health-topics/severeacute-respiratory-syndrome (accessed 22.08.2020)

Wu, G. (2020). Important roles of dietary taurine, creatine, carnosine, anserine and 4-hydroxyproline in human nutrition and health. Amino Acids, 52, 329-360.

https://doi.org/10.1007/s00726-020-02823-6

Xing, M., Ji, M., Hu, J., Zhu, T., Chen, Y., Bai, X., ... Jin, L. (2020). Snake Cathelicidin Derived Peptide Inhibits Zika Virus Infection. Frontiers in Microbiology, 11. https://doi.org/10.3389/fmicb.2020.01871

Zhang, H., Penninger, J.M., Li, Y., Zhong, N., Slutsky, A.S. (2020). Angiotensin-converting enzyme 2 (ACE2) as a SARS-CoV-2 receptor: Molecular mechanisms and potential therapeutic target. Intensive Care Medicine, 46(4), 586-590. https://doi.org/10.1007/s00134-020-05985-9

Zhang, L., Liu, Y . (2020). Potential interventions for novel coronavirus in China: A systematic review. Journal of Medical Virology, 92(5), 479-490.

https://doi.org/10.1002/jmv.25707

Zhu, Y., Tong, L., Nie, K., Wiwatanaratanabutr, I., Sun, P., Li, Q., ... Cheng, G. (2019). Host serum iron modulates dengue virus acquisition by mosquitoes. Nature Microbiology, 4(12), 2405-2415.

https://doi.org/10.1038/s41564-019-0555-x 